\title{
Exploring the Impact of Extroversion and Introversion Personality Types on EFL Learners' Preferences in Publishing Research Papers
}

\author{
${ }^{* 1}$ Ikrar Genidal Riadil, ${ }^{2}$ Muhammad Rauuf Oktavian Nur \\ ${ }^{* 1}$ Universitas Tidar, Magelang, Indonesia, ikrargenidal21@ gmail.com \\ ${ }^{2}$ Universitas Tidar, Magelang, Indonesia, m.rauufoktavian@gmail.com
}

Submitted: 10/07/2020 Revised: $31 / 10 / 2020 \quad$ Accepted: $18 / 11 / 2020$

How to cite this article: Riadil, I.G., Nur, M.R.O., (2020). Exploring the Impact of Extroversion and Introversion Personality Types on EFL Learners' Preferences in Publishing Research Papers. IJELR: International Journal of Education, Language, and Religion, 2(2), 47-53. http://doi.org/10.35308/ijelr.v2i2.2376

\begin{abstract}
Personality may affect our way to learn. Based on the essential role of various forms of personalities in the cycle of studying foreign languages and understanding foreign languages, this thesis seeks to explore the effect of extroversion and introversion on the identity of English as a foreign language learner in writing research articles. Fifty students are taking part in this study. Those participants are the fifth-semester students of Tidar University who take Teaching English as Foreign Language class. They have many papers from any lecture. They can produce more than three research papers in a year. Publishing their papers still become interesting topics for them. The researcher uses descriptive qualitative method to get the result. By giving a questionnaire to all the participants to find out their personality types and then asking about their preferences in publishing research papers. Based on the findings, researcher get main result, there are more extroverts EFL Learners than the introvert one. They could give wide perspectives about publishing their papers. Their perspectives on their preferences depend on any reason that supports the result.
\end{abstract}

\section{Keywords}

EFL learners; extroversion; introversion; personality; research paper

\section{Introduction}

Language is an integral component of the human being. By studying the language, people will talk with one another, get knowledge from one another and connect with one another (Riadil, 2020). Language has a big role in human life to make a relation in their environment. One analyst asserts that language is widely used in interaction among people who do not share the same first (or even second) language (Harmer, 2007). It indicates that language is very important to learn in human life.

In Indonesia, numerous students study English as a foreign language as their first language is a local language and the second language is Bahasa Indonesia (Riadil, 2020). English was being moved from lower education to higher education. English is becoming one of the subjects of the curriculum. There are four fundamental abilities individuals need to recognize before they study English, which are reading, writing, listening, and communicating (Riadil, 2019). 
The important aspects to conduct the success of English as a foreign language (EFL) learner are very interesting from cognitive factors to through the affective aspects. Affective aspects are important but really hard to describe them scientifically (Boroujeni, Roohani, \& Hasanimanesh, 2015). There are several attitude variables that involve their effect. Extroversion and introversion have a significant part to play in how students choose to get motivation and concentrate their attention. Extroverts tend to draw energy from external sources, but introverts tend to use their defensive behaviours and internal thoughts as the basis of their resources. According to Gross \& John (2003), The first stages in the Jung's method established the general purpose of the student in their thinking process. Extroverts mostly turn out their energy to their external behavior and tend to interact with the environment. Active experiences are so highly important for the extroverts' learners that they usually start to perform any assignments with little planning, then be aware of their error to improve their assignments. Since they spend so much time complying with the external world rather than the internal one, their thinking ability is quite abundantly obvious, and they incorporate more suggestions in practitioners or in conversation. They said that introvert language learners are often concentrating their attention on their internal world; they prefer to think and ponder.

Some study about the impact of personality factors are have huge variant of result, such as Alibakhshi (2011) Explored the influence of temperament and gender influences through all of the teaching practices of Iranian EFL students. He is observing those data by conducted the preference questionnaire of MBTI, Teaching Activities and Teaching Efficacy. The result shows that a significant influence was observed on those teacher activities preference by personality and gender of all of the teacher. In a different study by Kabiri (2015) investigated the same types of personality factors but in the other scope of learning. She focused on writing ability of EFL learners' perspective based on their extravert and introvert personality factors. The writing skill which she took is argumentative text by Iranian EFL learners in her school. Observing the EFL learners' skill in writing the argumentative text through their content, form and overall performances. She stated that introverted EFL learners' give their over performed extroverts in all of the categories (Maghfiroh \& Anwar, 2019). Writing a research paper include in the academic writing types of text. Then, based on Mansouri Nejad, Bijami, \& Ahmadi (2012) which conducted a research on academic writing ability of EFL Learners in Iranian college. He found that there no massive relation between writing ability with their EFL learners' personality. Depending on this finding, the general expectation of the effect of personality variables on the writing abilities of EFL learners is certainly distinct from the outcome of his study. People assumption about extroversion that over preformed the introversion EFL learners in language skill such as writing ability was rejected.

Moreover, EFL learners are not only have to write their research papers but also publish and presented that writing output. EFL learners especially in the writers' college have many assignments to do some research and write it down in a paper project. They can produce more than four papers in a year. Beside that massive output from writing skill, there are not means yet the publishing of their research papers is huge also. Our university has provided many journals, especially faculty of education and teacher training. That fact told me that they have great chance to publish their research paper to any conferences and journals. There are many universities that held any kind of national or international conferences. They also provide any kind of journals which is many learners can submit their research papers. Although, some of the conferences or journals will be very difficult for EFL students to get accepted as presenter but they still have huge chance. Some of the lecturer also give their massive support to supervise in their writing process of the research project to publishing them. Surprisingly, not all of them prefer to publish their papers. The research papers which have published are only in small percentage of all. Each of them has their perspectives and their reason. That condition makes the researcher get certain ideas to find out about this study. This study will use the writer's friends in the same year. They are EFL learners who take teaching English as foreign language class in third year of university. 


\section{Method}

The researcher used qualitative research method in this study in order to get the appropriate data. Patton \& Cochran (2007)stated that qualitative research is research method that specified by its goals, which is connected to understanding to any socio-aspect, and that certain methods generate words and sentences as data for analysis. Like what (Cam \& Tran, 2017) in (Riadil, 2020) stated that the questionnaire is a quite useful collection method because researchers can reach many participants and respondents in a short time and it does not need cost so much.

The participants of this study were fifty EFL learners of fifth semester of Tidar University students majoring in English Education Department in Tidar University. They were both EFL students with the age range of twenty to twenty-three years old learners who take teaching English as foreign language class. The researcher used MBTI test types to find out the EFL learners' personality types. Various researchers have defined various behavioral characteristics based on specific hypotheses. In attempt to discover out more about the behavioral characteristics of EFL students, several scholars used the Jungian personality styles assessed by the MBTI (Matthews \& Gustafsson, 2003). That process focused on measuring EFL learner's personalities on four types comprising of opposite pairs: Thinking-Feeling, Extraversion-Introversion, Judgment-Perception Sensation-Intuition, and resulting in sixteen possible psychological aspects (Carducci, 2009).

The researcher only focused this study on extraversion and introversion personality aspects. It consists of sixteen questions with two options for each item. Moreover, the writer asked the participants to complete set of questions designed to investigate three specific issues; EFL Learners' preferences in publishing their research paper, their perceptions about their reason in publishing it or not, and the appreciation that they want to get after publishing their paper.

The data collection techniques for this analysis were begun by providing the questionnaire, requesting the respondents to participate in the survey and eventually collecting the questionnaire which had been answered by the researcher.

\section{Results and Discussion}

Based on the result of the EFL learners' answers, there are 16 students are introverts and 34 learners are extroverts. It means EFL learners who has extroversion personality are $68 \%$ and the introversion students are $32 \%$. The participants were submitted their answer in a week. The researcher gives them a week to get their appropriate answer based on their personality.

\section{EFL Learners' Preferences in Publishing their Papers}

Most of the students who has introversion personality are do not want to publish their research papers. They have variety reasons for that publishing activities. Some of them think that they do not need to publish it. Some of them do not know about any journal and the system in publishing their research paper. They only have heard about the journal from their lecturers in the class. Finding out the journal systems, scope of research, or some national and international conferences are not their hobbies. Publishing their paper is not their priority. It is not important for them. Thinking about their assignments which perfectly finished were more important that publishing any research paper. That statement supported by the participant no. 13, he said that he does not care about the publishing activities. He wants to keep his research results by himself, so he would not present his paper in front of people. People also would not read his paper, except his lecturer. In the other hand, they did not know about any journal that do not need to present their research paper. They have very limited information about "call for paper" program which some journals have been declared. That conditions are very common on their circle because finding further information about those journals are not their plan and they will do that while their lecturers ask to them. The other EFL learner also give the support of these statements, participant number 21 stated that his paper is just such an appreciation to himself. He wants to put it on 
his files because he is not really concern about that field. Some of EFL learners also have same perception which they write their research paper only to complete their exam project. They were not interested with that kind of scope.

It was surprising that some introvert learners give their different point of view. Two of them want to publish their paper in any journals. They feel it is important to publish their finding to others scholar. Submitting their research paper which have done in the last semester will make them feel easy to revise and then submit it again to the journals or proceeding. Participant number 41 stated that she will publish her paper at the next conference. It will give other people chance to read her findings. She thinks her final result is important for the other. Some of EFL learners also agree with this statement but they more focused on the publishing their paper than presenting their findings. That statements supported by participant number 36. She would like to upload her paper through the national or international journal. Publishing their academic writing product will give them massive benefit for their future learning or study. Getting know that their research paper would be published make them happy and feel prestigious. However, even they want to publish it, they give more notes. They only want to present it together with their close friends. EFL introverts' learners will present their finding of paper project in three or four people in a team.

Moreover, based on the result the researcher could get the point which EFL learners with introversion personality have low priorities in publishing their research papers. Introverts' EFL learners have not great effort to publish and present their finding in their output products of writing skill. Even though, some of them have interesting perspective about the importance of publishing their paper to any journals. However, presenting their finding in front of the participants of any conferences is still problem for the introverts EFL learners.

In contrast, EFL learners with extroversion personality are became major population of the participants in this study. Learners who have many output products of academic writing in form of research papers want to make their finding accessible for the world. Almost of the extroverts' EFL learners prefer to publish their paper than keep them safe in their files. They got a challenge to present their findings in front of massive people. That statements are supported by many participants, such as participant number 8. Publishing her paper will determine how proper her paper, how beautiful words in her findings and the certificates for her achievements. Knowing that her research papers were accepted in some conferences make her feel happy and become a support system to conduct another research project in their favourite scope of study. Moreover, participant number 19 stated that she wants to share the benefits from her paper to all people in the world. Getting understand of the important of publishing academic research in the education world make her seriously focus to publish her research finding. She wants to see many Indonesian name while finding any articles in international journals on many websites. She also wants to get the best score in the certain lectures. Some of her lecturer promised to give the best score of that lecture if their students could publish their research paper in international journal and present the finding well. She also wants to support the credit points for her study program by publishing her research paper in international reputable journals. Then, publishing any research paper in any reputable journals will increase study program points and give the best result for the accreditation period.

Even almost of EFL learners with extroversion personality have stated that publishing their research papers are important. Some of them still give opposite respond. Their reason is so many, but the general reason is about the fee, time and so on. Some of reputable journal require certain charge for the publishing process. Any international or national conferences also have their certain price for the presenter. Even in some of conferences differentiate the presenter categories to give massive chance for the student presenter. That statements are supported by participant number 28 . She stated that she does not want to publish her finding this year because she wants to fix it first in the next chance. She needs more time to make the best paper to publish. Joining in some conferences also need certain time. The EFL learners stated that they feel difficult to arrange their schedule if they join to the conferences which 
need more than a day. They feel unsatisfied to leave too many lectures in a week. Some activities from their study program, faculty or universities are also held in weekdays. That condition makes them need to think deeper when applying their research papers into any conferences or seminar. The other participants stated that he does not have enough money to pay the conference fee. As we know, each conference and seminar need to pay first and most of them have high rates. Those statements are definitely common problem for EFL learners who want to publish their research paper to any international or national journals. Some high reputable journal does not need some fee to pay the publishing process, but they have the highest standard of the quality of any academic research papers. Furthermore, not all the EFL learners have high income for their study activities. Some of them also feel hard to save their money to go to any international or national conferences.

As it was revealed, EFL learners with extroversion personality have high priorities in publishing their research papers. Publishing their research paper in reputable journals are challenging activities which give them support systems to do their best in finishing their academic research project. They want to submit to any journals to share their findings to people in the world. Even some of them have different perspective of publishing papers. Arranging the schedule is one of the problems for those extroverts EFL learners to apply their research paper to any journals. They need to arrange them in early semester so they would not face difficult choices while the semester is still running. The most popular obstacles for those EFL learners are about the money. They do not have enough money to pay the conference fee or charge of publishing process, and the accommodation charge when they have any conferences outside the city, province or even in the overseas.

\section{Types of appreciation that EFL learners' want to get}

Finishing their papers needs great effort than publishing it needs a certain purpose. Some of EFL Learners with introversion personality want to finish it and get thanks to appreciate them. It will be more than enough for them when their lecturers give applause, big thumbs up, or thanks expression for their work. Most of them are do not need any appreciation words because finishing their paper project is enough for their self-satisfied. The introverts EFL learners will feel free and very satisfied when they have finished their research papers on time. Some of them will feel free to do their hobbies to killing their spare time when their academic research project is clearly finished. All of them need a vacation time after finishing all their paper project. That statements are supported by participant number 21 . He stated that he only wants to finish it and submit it to his lecturer. It more than enough for his self-satisfied.

Moreover, EFL learners with extroversion personality have their perspective about appreciation. Some of them think that publishing in any journals is the best appreciation for their effort and process. Especially, accepting news from any reputable international journals will give them high prestigious. It will give them high effort to create another research paper. The other participants want to get some certain categories in some national or international conferences. Even not all the conferences provide that facilities. Some international conferences have certain categories such as, the best paper, the best presenter, and the other categories. The rest of them want to get some appreciation from their lecturer. Some feedback will give them massive moral support to submitting their next academic product. It will give them more support to finish their other research papers. That statements are supported by participant number 17 and 38. They want to get the best presenter categories in some international conferences. They also want to get accepted in reputable journals. That appreciation will make them happy and give them special support systems to finishing other research papers. Summer paradise is one of the most valuable activities for them after completing their research paper. They need huge vacation with their family, friends, or couple. In other hand, healthy life after finishing their academic project are important achievement. 


\section{Conclusion}

Based on the discussion above, the researcher gets some of the conclusion points. Massive effects were given to the EFL learners' preference in publishing their research papers by those two types of personality aspects. EFL learners with extroversion personalities prefer to publish and submit their papers to any international or national journals. They also want some appreciation categories for their work. Published paper in reputable journals are the most important rewards for them. On the other hand, EFL learners with introversion personality prefer to keep their paper trough their files. They do not need any specific appreciation. Finishing and submitting their paper to their lecturers are more than enough for them.

The future research about these types should have wide range of participants from many EFL learners' background and huge heterogenic environment. Combining the method with any quantitative analysis will be better for the next studies to get the most appropriate data of findings. The other researcher about this study should use other personality factors in attempt to find out the impact on the EFL learners' preferences in publishing their research papers. The other personality factors can be compiled with the factors which this study discuss, so the result of the future research will be very interesting enough to publish in any reputable international journals.

\section{References}

Alibakhshi, G. (2011). The Impacts of Gender and Personality Types on Iranian EFL Teachers' Teaching Efficacy and Teaching Activities Preferences. Iranian Journal of Applied Linguistics (IJAL), 14(1), $1-22$.

Boroujeni, A. A. J., Roohani, A., \& Hasanimanesh, A. (2015). The Impact of Extroversion and Introversion Personality Types on EFL Learners' Writing Ability. Theory and Practice in Language Studies. DOI:10.17507/tpls.0501.29

Cam, L., \& Tran, T. M. T. (2017). An evaluation of using games in teaching English grammar for first year English-majored students at Dong Nai Technology University. International Journal of Learning, Teaching and Educational Research, 16 (7): 55-71.

Carducci, B. J. (2009). The Psychology of Personality: Viewpoints, Research, and Applications. In Wiley Blackwell.

Gross, J. J., \& John, O. P. (2003). Individual Differences in Two Emotion Regulation Processes: Implications for Affect, Relationships, and Well-Being. Journal of Personality and Social Psychology. DOI : 10.1037/0022-3514.85.2.348

Harmer, J. (2007). The Practice of English Languag Teaching. 394-409.

Kabiri, M. (2015). Guided Task-based Planning and Writing Accuracy: The Case of Iranian Lowerintermediate EFL Learners. Theory and Practice in Language Studies. DOI: 10.17507/tpls.0503.10

Maghfiroh, A., \& Anwar, A. C. (2019). L1 Use in L2: Should We Omit It? Reexamining the L2-Only Policy in Foreign Language Classroom. International Journal of Education, Language, and Religion, 1(1), 26-31.

Mansouri Nejad, A., Bijami, M., \& Ahmadi, M. R. (2012). Do Personality Traits Predict Academic Writing Ability? An EFL Case Study. English Linguistics Research. DOI: 10.5430/elr.v1n2p145

Matthews, J., \& Gustafsson, J.-åke. (2003). Esrtogen signaling: a subtle balance between ER $\alpha$ and ER $\beta$. Molecular Interventions.

Quinn Patton, M., \& Cochran, M. (2007). A Guide to Using Qualitative Research Methodology. In Medecins Sans Frontieres. 
Riadil, I. G. (2019). The EFL Learner's Perspectives About Accuracy, Fluency, and Complexity in Daily Routines. Journal of Research on Applied Linguistics, Language, and Language Teaching, 2(2): $160-166$.

Riadil, I. G. (2020). A Study of Students' Perception: Identifying EFL Learners' Problems in Speaking Skill. International Journal of Education, Language, and Religion, 2(1): 31-38.

Riadil, I. G. (2020). Does Oral Presentation Affect The Development of the Studnets Ability to Speak in EFL Classroom? Social Sciences, Humanities and Education Journal (SHE Journal), 1(2), 1321.

Riadil, I. G. (2020). Investigating EFL Learners Reading Comprehension Problems and Strategies in TIDAR University. Journal of English Language and Language Teaching, 4(1), 48-58. 